\title{
LigpKa-a database of pKa values for small molecule ligands designed for the use in structure-based pKa calculations
}

\author{
P Czodrowski ${ }^{1,2^{*}}$, CR Søndergaard ${ }^{3,4}$, S Dohm², G Klebe ${ }^{2}$, JE Nielsen ${ }^{4}$ \\ From 6th German Conference on Chemoinformatics, GCC 2010 \\ Goslar, Germany. 7-9 November 2010
}

Electrostatic forces play a large role in determining the strength of protein-ligand interactions, and the calculation of pKa value shifts upon ligand binding is therefore an important component of any accurate protein-ligand binding calculation. However, such pKa calculations are rarely performed in virtual screening experiments due to the unavailability of ligand solution pKa values and the difficulty in generating the required charge distributions for each ligand protonation state. We present a freely available web-based database of small-molecule pKa values that automates the task of retrieving protonation states and solution pKa values for small-molecule ligands so that these can be used with tools such as PRODRG and PDB2PQR for generating the necessary parameters for a structure-based pKa calculation of a protein-ligand complex. The database contains a total of $348 \mathrm{pKa}$ values and represents a significant step towards performing accurate automated $\mathrm{pKa}$ value calculations in virtual screening experiments.

\footnotetext{
Author details

'Merck KGaA, Frankfurter Straße 250, D-64293 Darmstadt, Germany. ${ }^{2}$ PhilippsUniversity Marburg, Institute of Pharmaceutical Chemistry, Marbacher Weg 6, 35032 Marburg, Germany. ${ }^{3}$ Department of Chemistry, University of Copenhagen, Universitetsparken 5, 2100 Copenhagen, Denmark. ${ }^{4}$ School of Biomolecular and Biomedical Science, Conway Institute, UCD, Dublin 4, Ireland.
}

Published: 19 April 2011

\footnotetext{
* Correspondence: paul.czodrowski@merck.de

'Merck KGaA, Frankfurter Straße 250, D-64293 Darmstadt, Germany

Full list of author information is available at the end of the article
}

doi:10.1186/1758-2946-3-S1-P21

Cite this article as: Czodrowski et al:: LigpKa-a database of pKa values for small molecule ligands designed for the use in structure-based pKa calculations. Journal of Cheminformatics 2011 3(Suppl 1):P21.

\footnotetext{
Publish with ChemistryCentral and every scientist can read your work free of charge

"Open access provides opportunities to our colleagues in other parts of the globe, by allowing anyone to view the content free of charge."

W. Jeffery Hurst, The Hershey Company.

- available free of charge to the entire scientific community

- peer reviewed and published immediately upon acceptance

- cited in PubMed and archived on PubMed Central

- yours - you keep the copyright

Submit your manuscript here

http://www.chemistrycentral.com/manuscript/

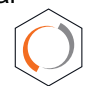

Chemistry Central
} 